\title{
Carbothermic Reduction of Synthetic Chromite with/without the Addition of Iron Powder
}

\author{
Xianfeng HU, ${ }^{1,2) *}$ Lidong TENG, ${ }^{3)}$ Haijuan WANG, ${ }^{4)}$ Lena SUNDOVIST ÖKVIST, ${ }^{1,2)}$ Qixing YANG, ${ }^{2)}$ \\ Bo BJÖRKMAN ${ }^{2)}$ and Seshadri SEETHARAMAN ${ }^{31}$
}

1) Process Metallurgy Department, Swerea MEFOS AB, PO Box 812, SE-971 25, Luleå, Sweden.

2) Department of Civil, Environmental and Natural Resources Engineering, Luleå University of Technology, SE-971 87, Luleå,

Sweden. $\quad 3)$ Division of Materials Process Science, KTH-Royal Institute of Technology, Stockholm, Sweden.

4) State Key Laboratory of Advanced Metallurgy, University of Science and Technology, Beijing, China.

(Received on June 10, 2016; accepted on August 17, 2016; J-STAGE Advance published date: October $25,2016)$

\begin{abstract}
Carbothermic reduction of chromite is an important industrial process for extracting chromium from the chromite. To have a better understanding of the effect of iron on the carbothermic reduction of chromite, the reduction of synthetic chromite $\left(\mathrm{FeCr}_{2} \mathrm{O}_{4}\right)$ by graphite with/without the addition of iron powder was investigated in this paper by Thermogravimetric Analysis (TGA) in argon atmosphere. The fractional reduced samples were examined by SEM/EDS and XRD analysis, and the reduction process was thermodynamically and kinetically evaluated. The experimental results show that the iron powder addition enhances the reduction of $\mathrm{FeCr}_{2} \mathrm{O}_{4}$ and this effect increases when increased amounts of iron powder are added. This phenomenon is attributed to the in situ dissolution of chromium into the iron and mixed carbide $(\mathrm{Cr}, \mathrm{Fe})_{7} \mathrm{C}_{3}$, which can decrease the activity of the nascent chromium formed by the reduction of the $\mathrm{FeCr}_{2} \mathrm{O}_{4}$. The experimental results indicate that the reduction of $\mathrm{FeCr}_{2} \mathrm{O}_{4}$ with up to 80 wt. $\%$ iron powder addition is likely to be a single-step process and the kinetic analysis suggests that the reduction reaction is likely to be either (a) chemical reaction at the surface of $\mathrm{FeCr}_{2} \mathrm{O}_{4}$ or (b) diffusional dissolution of the product $\left(\mathrm{FeCr}_{2}\right)$ into the iron/alloy particles or the mixed control of (a) and (b).
\end{abstract}

KEY WORDS: thermogravimetric analysis; chromite; carbothermic reduction; kinetics.

\section{Introduction}

Carbothermic reduction of chromite ore is an important process for the pre-reduction of chromite ore as well as its follow-up smelting reduction in the submerged arc furnace. To have a better understanding of the reduction behavior of chromite ore, numerous investigations have been carried out on the reduction of synthetic iron chromite $\left(\mathrm{FeCr}_{2} \mathrm{O}_{4}\right)$ with carbon as the reductant. ${ }^{1-7)}$ The advantage of studying the reduction reaction using synthetic $\mathrm{FeCr}_{2} \mathrm{O}_{4}$ spinel is to gain an understanding of the mechanism underlying the reaction in the absence of gangue materials. Besides $\mathrm{FeCr}_{2} \mathrm{O}_{4}$, carbothermic reduction of other synthetic spinel compounds of $\mathrm{Cr}$ and $\mathrm{Cr}_{2} \mathrm{O}_{3}$ have also been investigated by various researchers. ${ }^{1-3,8,9)}$ The essential features of these investigations are summarized in Table 1, and an analysis of the results obtained so far is given below:

(1) Reduction sequence. With no exception, $\mathrm{Cr}_{2} \mathrm{O}_{3}$ was observed as an intermediate during the reduction process of $\mathrm{FeCr}_{2} \mathrm{O}_{4}$. This indicates that the reduction of $\mathrm{FeO}$ component precedes that of $\mathrm{Cr}_{2} \mathrm{O}_{3}$ component in $\mathrm{FeCr}_{2} \mathrm{O}_{4}$. The co-existence of unreduced $\mathrm{FeCr}_{2} \mathrm{O}_{4}, \mathrm{Cr}_{2} \mathrm{O}_{3}$ and

* Corresponding author: E-mail: xianfeng.hu@swerea.se

DOI: http://dx.doi.org/10.2355/isijinternational.ISIJINT-2016-337 chromium-containing products (such as $\mathrm{Cr}_{7} \mathrm{C}_{3}$ ) indicates that the reduction of $\mathrm{FeO}$ component and that of $\mathrm{Cr}_{2} \mathrm{O}_{3}$ component overlap.

(2) Reduction products. For the reduction of iron-containing chromium spinel compounds, carbide phase $\left(\mathrm{Cr}_{7} \mathrm{C}_{3}\right.$ or $\left.(\mathrm{Cr}, \mathrm{Fe})_{7} \mathrm{C}_{3}\right)$ and metallic phase $(\mathrm{Fe}, \mathrm{Fe}-\mathrm{Cr}$ alloy or $\mathrm{Fe}-$ $\mathrm{Cr}-\mathrm{C}$ alloy) were commonly found to be the reduction products; for the reduction of iron-free chromium spinel compounds, a carbide phase, $\mathrm{Cr}_{3} \mathrm{C}_{2}$, was found to be the reduction product; for the reduction of $\mathrm{Cr}_{2} \mathrm{O}_{3}$, three different kinds of carbides $\left(\mathrm{Cr}_{3} \mathrm{C}_{2}, \mathrm{Cr}_{7} \mathrm{C}_{3}\right.$ and $\left.\mathrm{Cr}_{23} \mathrm{C}_{6}\right)$ and metallic chromium were found to be the reduction products.

(3) Reduction mechanisms. The diversity of the reduction mechanisms reported by different investigators indicates that the carbothermic reduction of $\mathrm{FeCr}_{2} \mathrm{O}_{4}$ and $\mathrm{Cr}_{2} \mathrm{O}_{3}$ is a complex process. Besides the differences in the experimental conditions, the complexity of the reduction is attributed to: (a) the reduction of component $\mathrm{FeO}$ and that of $\mathrm{Cr}_{2} \mathrm{O}_{3}$ overlap, which could be governed by different mechanisms; ${ }^{3,4,6,10)}$ (b) a molten metallic phase is likely to form in the case of high experimental temperature and high amount of carbon addition (high $\mathrm{C} / \mathrm{O}$ ratio), and the presence of this molten phase could make the reduction shift towards a smelting reduction mechanism; ${ }^{11)}$ (c) the formation of carbides could change the 
Table 1. A summary of the carbothermic reduction of synthetic chromite and $\mathrm{Cr}_{2} \mathrm{O}_{3}$ from the literature.

\begin{tabular}{|c|c|c|c|}
\hline Reference & $\begin{array}{l}\text { Reactants, maximum experimental temperatures and } \mathrm{C}: \mathrm{O}^{*} \\
\text { (mole ratio) }\end{array}$ & Products/intermediates & Proposed mechanism/rate-limiting step \\
\hline \multirow{3}{*}{$1,2)$} & $\begin{array}{l}\text { ' } \mathrm{FeCr}_{2} \mathrm{O}_{4}+\text { graphite', } 1453 \mathrm{~K} \text { and } 1.375 \\
\text { ' }\left(\mathrm{Fe}_{0.5} \mathrm{Mg}_{0.5}\right) \mathrm{Cr}_{2} \mathrm{O}_{4}+\text { graphite', } 1513 \mathrm{~K} \text { and } 1.43\end{array}$ & $\begin{array}{l}\text { austenite, } \mathrm{Cr}_{2} \mathrm{O}_{3},(\mathrm{Fe}, \mathrm{Cr})_{3} \mathrm{C} \text { and } \\
(\mathrm{Cr}, \mathrm{Fe})_{7} \mathrm{C}_{3} \\
(\mathrm{Cr}, \mathrm{Fe})_{7} \mathrm{C}_{3} \text { and } \mathrm{Cr}_{2} \mathrm{O}_{3}\end{array}$ & The Boudouard reaction \\
\hline & $\begin{array}{l}\text { ' } \mathrm{MgCr}_{2} \mathrm{O}_{4}+\text { graphite', } 1513 \mathrm{~K} \text { and } 1.125 \\
\text { '( }\left(\mathrm{Fe}_{0.5} \mathrm{Mg}_{0.5}\right)\left(\mathrm{Cr}_{0.8} \mathrm{Al}_{0.2}\right)_{2} \mathrm{O}_{4}+\text { graphite', } 1603 \mathrm{~K} \text { and } 1.55\end{array}$ & $\begin{array}{l}\mathrm{Cr}_{3} \mathrm{C}_{2} \text { and } \mathrm{MgO} \\
\mathrm{Cr}_{2} \mathrm{O}_{3}, \mathrm{MgAl}_{2} \mathrm{O}_{4} \text { and }(\mathrm{Cr}, \mathrm{Fe})_{7} \mathrm{C}_{3}\end{array}$ & $\begin{array}{l}\text { Mixed control of the Boudouard reac- } \\
\text { tion and gaseous reduction }\end{array}$ \\
\hline & $\begin{array}{l}\text { 'Mg( }\left(\mathrm{Cr}_{0.6} \mathrm{Al}_{0.4}\right)_{2} \mathrm{O}_{4}+\text { graphite' } \\
1633 \mathrm{~K} \text { and } 1.94\end{array}$ & $\mathrm{MgO}, \mathrm{MgAl}_{2} \mathrm{O}_{4}$ and $\mathrm{Cr}_{3} \mathrm{C}_{2}$ & Mainly gaseous reduction \\
\hline 3) & $\begin{array}{l}\text { ' } \mathrm{FeCr}_{2} \mathrm{O}_{4}+\text { carbon', } 1773 \mathrm{~K} \text { and } 0.52 / 0.94 / 1.17 / 2 \\
\text { ' }\left(\mathrm{Fe}_{0.4} \mathrm{Mg}_{0.6}\right)\left(\mathrm{Fe}_{0.4} \mathrm{Cr}_{0.6}\right)_{2} \mathrm{O}_{4}+\text { carbon', } 1773 \mathrm{~K} \text { and } 0.42 / 1.62\end{array}$ & $\begin{array}{l}\alpha \text {-Fe, } \mathrm{Cr}_{2} \mathrm{O}_{3} \text { and } \mathrm{Cr}_{7} \mathrm{C}_{3} \\
\alpha-\mathrm{Fe}, \mathrm{MgCr}_{2} \mathrm{O}_{4}, \mathrm{Cr}_{7} \mathrm{C}_{3}\end{array}$ & $\begin{array}{l}\text { Two different diffusion controlled } \\
\text { mechanisms for the first stage and the } \\
\text { second stage }\end{array}$ \\
\hline 4) & ' $\mathrm{FeCr}_{2} \mathrm{O}_{4}+$ graphite', $1573 \mathrm{~K}$ and 1.2/1.25/1.3 & $\mathrm{Fe}, \mathrm{Cr}_{2} \mathrm{O}_{3}$ and $\mathrm{Cr}_{3} \mathrm{O}_{4}$ & Diffusion of oxygen (in the first stage) \\
\hline 5) & $\begin{array}{l}\text { ' } \mathrm{FeCr}_{2} \mathrm{O}_{4}+\text { graphite' } \\
1823 \mathrm{~K} \text { and } 1.17 / 1.20\end{array}$ & $\begin{array}{l}\mathrm{Fe}-\mathrm{Cr} \text { alloy, } \mathrm{Cr}_{2} \mathrm{O}_{3}, \mathrm{Cr}_{7} \mathrm{C}_{3} \text { and } \\
(\mathrm{Cr}, \mathrm{Fe})_{7} \mathrm{C}_{3}\end{array}$ & Zeroth order reaction in the initial stage \\
\hline 6) & ' $\mathrm{FeCr}_{2} \mathrm{O}_{4}+$ graphite', $1673 \mathrm{~K}$ and 1 & $\begin{array}{l}\mathrm{Fe}-\mathrm{Cr} / \mathrm{Fe}-\mathrm{Cr}-\mathrm{C} \text { alloy, } \mathrm{Cr}_{2} \mathrm{O}_{3} \text { and } \\
\mathrm{Cr}_{7} \mathrm{C}_{3}\end{array}$ & $\begin{array}{l}\text { First stage by nucleation and second } \\
\text { stage by crystallo-chemical transforma- } \\
\text { tion. }\end{array}$ \\
\hline 8) & ' $\mathrm{Cr}_{2} \mathrm{O}_{3}+$ graphite', $1673 \mathrm{~K}$ and 1 & $\mathrm{Cr}_{3} \mathrm{C}_{2}, \mathrm{Cr}_{7} \mathrm{C}_{3}, \mathrm{Cr}_{23} \mathrm{C}_{6}$ and $\mathrm{Cr}$ & $\begin{array}{l}\text { Diffusion of } \mathrm{CO} / \mathrm{CO}_{2} \text { through product } \\
\text { layer in the later stage }\end{array}$ \\
\hline 9) & ' $\mathrm{Cr}_{2} \mathrm{O}_{3}+$ graphite', $1673 \mathrm{~K}$ and 1 & - & $\begin{array}{l}\text { Gas-phase mass transport of CO away } \\
\text { from the reactants }\end{array}$ \\
\hline
\end{tabular}

$\mathrm{O}^{*}$ indicates oxygen bonded to iron and chromium.

reduction mechanism. ${ }^{8)}$

Within the scope of chromite reduction, a literature survey shows that the reduction of chromite (both synthetic and natural) in the presence of fluxes or metals has been of great interest. Katayama et al. ${ }^{12)}$ investigated the effect of addition of chlorides, carbonates, fluorides and borates on the reduction of synthetic chromite and chromite ore. These authors found that borates had the strongest promoting effect on the reduction, and they attributed this to the fact that borates facilitated the diffusion of ionic species and the grain growth of the metal produced. Ding et al. ${ }^{13)}$ investigated the effect of lime addition on the carbothermic reduction of chromite ore. They found that the reduction rate and extent increased with increasing addition of lime. The explanation offered by these authors is that lime possibly enhances the nucleation and/or interfacial reaction in the early stage and facilitates the solid-diffusion process in the later stage. Weber et al. ${ }^{14-16)}$ investigated the effect of silica addition on the reduction of chromite ore. They found that silica affected the reduction at and above $1673^{\circ} \mathrm{C}$ and the overall process shifted toward a more chemical-reactioncontrolled mechanism. Van Deventer ${ }^{17)}$ investigated the effect of various additives on the reduction of chromite ore. Although all the additives that were added to the chromite ore had some effect on the reduction, the author found that $\mathrm{K}_{2} \mathrm{CO}_{3}, \mathrm{Na}_{2} \mathrm{O}_{2}$ and $\mathrm{CaO}$ enhanced the carbothermic reduction of chromite ore significantly; $\mathrm{SiO}_{2}$ and $\mathrm{Fe}(5$ wt. $\%$ and 15 wt. $\%$ by the weight sum of chromite ore and iron) had a moderate catalytic influence; $\mathrm{Cr}$ exerted very little influence on the reduction process; $\mathrm{Al}_{2} \mathrm{O}_{3}$ and $\mathrm{MgO}$ had negative effects on the rate of reduction. Wang et al. ${ }^{7}$ investigated the effect of various additives on the carbothermic reduction of $\mathrm{FeCr}_{2} \mathrm{O}_{4}$. They found that $\mathrm{CaO}$ and $\mathrm{Al}_{2} \mathrm{O}_{3}$ enhanced the reduction, while $\mathrm{MgO}$ and $\mathrm{SiO}_{2}$ hindered the reduction.
Similar to the reduction of $\mathrm{FeCr}_{2} \mathrm{O}_{4}$ in the presence of iron, various investigations were carried out on the reduction of $\mathrm{Cr}_{2} \mathrm{O}_{3}$ (in solid form or in the liquid form in the slag) in the presence of iron oxide or iron powder. The results showed that iron oxide and iron powder both had a pronounced effect on the reduction with respect to the reduction rate and chromium recovery. $5,11,18-21$ )

According to the available literature the mechanism of the iron addition on the reduction of chromite ore or $\mathrm{FeCr}_{2} \mathrm{O}_{4}$ is not fully understood. In the present study, the carbothermic reduction of synthetic iron chromite $\left(\mathrm{FeCr}_{2} \mathrm{O}_{4}\right)$ with/without the addition of metallic iron powder was investigated by Thermogravimetric Analysis (TGA) under non-isothermal conditions. The main purpose is to clarify the mechanism of carbothermic reduction of $\mathrm{FeCr}_{2} \mathrm{O}_{4}$ with the addition of iron powder. This may help to understand the reduction behaviors of chromite ore with different $\mathrm{Fe} / \mathrm{Cr}$ ratios and, further, it may also help to find alternative ways to utilize the chromite ore for chromium alloying with respect to obtaining a higher chromium yield at relatively lower temperatures.

\section{Theoretical}

The reactions in the $\mathrm{FeCr}_{2} \mathrm{O}_{4}$-carbon mixture can be classified as direct reactions and indirect reactions. The direct reactions proceed at contact points of chromite and carbon (possibly also carbides ${ }^{11)}$ ) particles and these reactions are shown as Eqs. (1)-(3). For the metallic oxide-carbon (or carbides) reduction system, it is generally believed that indirect reactions prevail during the whole course of the reduction $^{9,22-27)}$ and a coupling phenomenon of carbon gasification and metal oxide reduction takes place. ${ }^{28)}$ The indirect reactions of $\mathrm{FeCr}_{2} \mathrm{O}_{4}$ reduction can be expressed by Eqs. (4)-(6) and these reactions are accompanied by the 
carbon gasification reactions shown as Eqs. (7), (8).

$$
\begin{array}{r}
\mathrm{FeCr}_{2} \mathrm{O}_{4}(\mathrm{~s})+[\mathrm{C}](\mathrm{s})=\mathrm{Fe}(\mathrm{s})+\mathrm{Cr}_{2} \mathrm{O}_{3}(\mathrm{~s})+\mathrm{CO}(\mathrm{g}) \ldots(1) \\
7 \mathrm{Cr}_{2} \mathrm{O}_{3}(\mathrm{~s})+27[\mathrm{C}](\mathrm{s})=2 \mathrm{Cr}_{7} \mathrm{C}_{3}(\mathrm{~s})+21 \mathrm{CO}(\mathrm{g}) \ldots \ldots(2) \\
\mathrm{Cr}_{7} \mathrm{C}_{3}(\mathrm{~s})+\mathrm{Cr}_{2} \mathrm{O}_{3}(\mathrm{~s})=9[\mathrm{Cr}](\mathrm{s})+3 \mathrm{CO}(\mathrm{g}) \ldots \ldots . .(3) \\
\mathrm{FeCr}_{2} \mathrm{O}_{4}(\mathrm{~s})+\mathrm{CO}(\mathrm{g})=[\mathrm{Fe}](\mathrm{s})+\mathrm{Cr}_{2} \mathrm{O}_{3}(\mathrm{~s})+\mathrm{CO}_{2}(\mathrm{~g}) \ldots(4) \\
7 \mathrm{Cr}_{2} \mathrm{O}_{3}(\mathrm{~s})+33 \mathrm{CO}(\mathrm{g})=2 \mathrm{Cr}_{7} \mathrm{C}_{3}(\mathrm{~s})+27 \mathrm{CO}_{2}(\mathrm{~g}) \ldots .(5) \\
\mathrm{Cr}_{2} \mathrm{O}_{3}(\mathrm{~s})+3 \mathrm{CO}(\mathrm{g})=2[\mathrm{Cr}](\mathrm{s})+3 \mathrm{CO}_{2}(\mathrm{~g}) \ldots \ldots . .(6) \\
\mathrm{Cr}_{7} \mathrm{C}_{3}(\mathrm{~s})+3 \mathrm{CO}(\mathrm{g})=7[\mathrm{Cr}](\mathrm{s})+6 \mathrm{CO}(\mathrm{g}) \ldots \ldots \ldots(7) \\
{[\mathrm{C}](\mathrm{s})+\mathrm{CO}_{2}(\mathrm{~g})=2 \mathrm{CO}(\mathrm{g}) \ldots \ldots \ldots \ldots \ldots . . . . .(8)}
\end{array}
$$

To thermodynamically evaluate the carbothermic reduction of $\mathrm{FeCr}_{2} \mathrm{O}_{4}$, a general form of the Gibbs energy term for the above mentioned indirect reactions can be written as Eq. (9).

$$
\Delta G \approx \Delta_{r} G^{\circ}+R T \ln \left(\frac{a_{B}}{a_{A}} \cdot \frac{P_{C O 2}}{P_{C O}}\right)
$$

Where $\Delta_{\mathrm{r}} \mathrm{G}^{\circ}$ represents the standard Gibbs energy of reaction; $\mathrm{a}_{\mathrm{A}}$ and $\mathrm{a}_{\mathrm{B}}$ represent the activities of the reactant and the product, respectively; $P_{\mathrm{CO} 2}$ and $P_{\mathrm{CO}}$ represent the partial pressures of $\mathrm{CO}_{2}$ and $\mathrm{CO}$, respectively.

From Eq. (9), it can be seen that the indirect reactions are influenced by the activities of the reactant and the product as well as the ratio of the partial pressures of $\mathrm{CO}_{2}$ to $\mathrm{CO}$. During the reduction $\mathrm{FeCr}_{2} \mathrm{O}_{4}$ and its intermediate $\mathrm{Cr}_{2} \mathrm{O}_{3}$ are present in the system at unit activity (pure solid substances of $\mathrm{FeCr}_{2} \mathrm{O}_{4}$ and $\mathrm{Cr}_{2} \mathrm{O}_{3}$ are taken as the reference states). However, the products (iron/chromium and carbide) are likely to be in solution, either as $\mathrm{Fe}-\mathrm{Cr}-\mathrm{C}$ solid or liquid solution or mixed carbide; their activities consequently being less than unity (bcc-Fe and bcc-Cr are taken the as the reference states). From Eq. (9), it is noted that the indirect reactions corresponding to Eqs. (4)-(6) would be thermodynamically enhanced if the activity of the product, especially the as-formed chromium in the metallic phase, can be decreased. By taking temperature as the abscissa and $\log \left(P_{\mathrm{CO}_{2}} / P_{\mathrm{CO}}\right)$ as the ordinate, an equilibrium diagram for the reactions in Eqs. (4)-(8) at a total pressure of $1 \mathrm{~atm}$ $\left(10^{5} \mathrm{~Pa}\right)$ is plotted in Fig. 1. It is seen that the reaction corresponding to Eq. (4) takes place more easily than that of Eq. (5), thereby explaining the initial reduction of iron in the $\mathrm{FeCr}_{2} \mathrm{O}_{4}$ followed by chromium in the $\mathrm{Cr}_{2} \mathrm{O}_{3}$. It is noted from Fig. 1 that the reactions corresponding to Eqs. (6), (7) are also thermodynamically feasible at the temperature range $1273-1723 \mathrm{~K}$ if the activity of chromium can be lowered below a critical value.

In order to achieve the lowering of the activity of chromium, iron powder is added into the $\mathrm{FeCr}_{2} \mathrm{O}_{4}$-graphite mixture in this investigation. The reduction reactions are expected to be enhanced by the in situ dissolution of nascent chromium formed (i.e., direct dissolution of chromium on site) in iron powder, thereby lowering the activity of chromium.

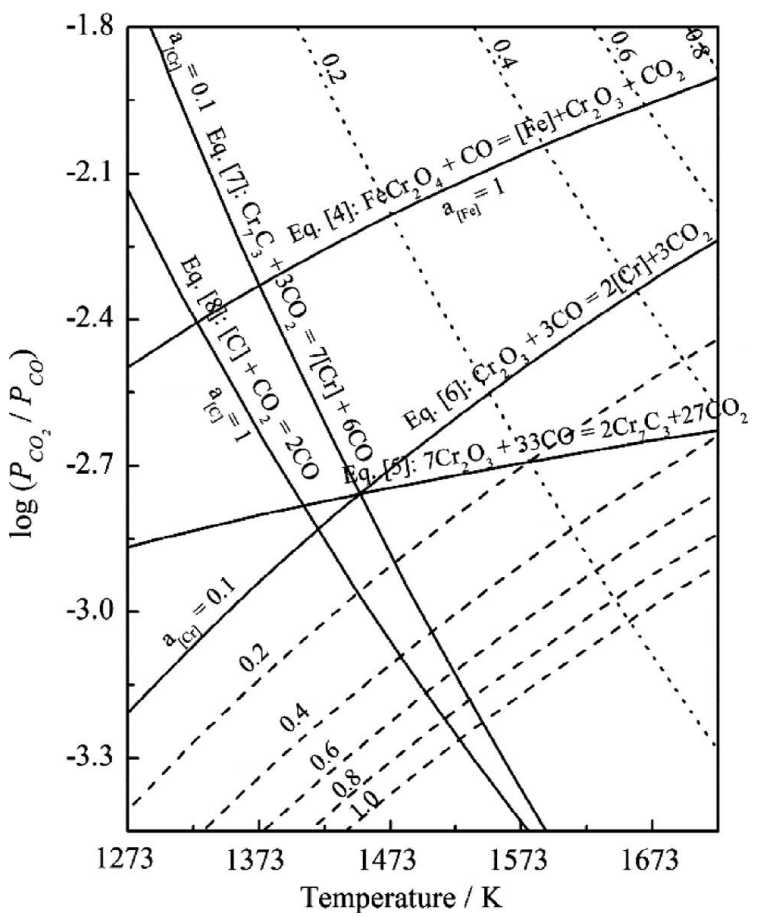

Fig. 1. Equilibrium diagram $\left(\log \left(P_{\mathrm{CO} 2} / \mathrm{P}_{\mathrm{CO}}\right)\right.$ vs. temperature $)$ for the reactions corresponding to Eqs. (4)-(8) (the data used to plot this diagram are derived from the FactPS database of software package Factsage $6.3,{ }^{29)} \mathrm{P}_{\mathrm{CO}}+\mathrm{P}_{\mathrm{CO} 2} \approx 1.0 \mathrm{~atm}$; the reference states for $\mathrm{C}, \mathrm{Cr}$ and $\mathrm{Fe}$ are graphite, bcc- $\mathrm{Cr}$ and bcc-Fe, respectively).

\section{Experimental Procedures}

Five different test samples were prepared by thoroughly mixing synthetic iron chromite $\left(\mathrm{FeCr}_{2} \mathrm{O}_{4}\right)$ powder $(\leq 30 \mu \mathrm{m}$, estimated by SEM) with different proportions of analytically pure iron powder $(\leq 10 \mu \mathrm{m}$, purity $\geq 99.5 \%)$ and graphite powder ( $\leq 50 \mu \mathrm{m}$, purity $\geq 99 \%)$ in an agate mortar to ensure the homogeneity of the samples. A detailed description on the preparation of the synthetic $\mathrm{FeCr}_{2} \mathrm{O}_{4}$ was given in a previous publication. ${ }^{30)}$ The iron content in the five samples (numbered S1, S2, S3, S4 and S5) were 0, 20 wt.\%, 40 wt. $\%, 60$ wt. $\%$ and 80 wt. $\%$, respectively, with respect to the sum of the masses of $\mathrm{FeCr}_{2} \mathrm{O}_{4}$ and iron powder. The mass of graphite added to the mixtures was $20 \mathrm{wt} \%$ in excess of what was needed to stoichiometrically reduce all $\mathrm{FeCr}_{2} \mathrm{O}_{4}$ in each sample to metallic iron and chromium according to an overall reaction described in Eq. (10).

$$
\mathrm{FeCr}_{2} \mathrm{O}_{4}(\mathrm{~s})+4 \mathrm{C}(\mathrm{s})=\mathrm{Fe}(\mathrm{s})+2 \mathrm{Cr}(\mathrm{s})+4 \mathrm{CO}(\mathrm{g}) \ldots
$$

The experiments were carried out in the Netzsch 449C apparatus, which has the capacity for simultaneous thermogravimetric analysis (TGA) and differential scanning calorimetry (DSC). In each experiment a carefully weighed sample of $20 \pm 0.5 \mathrm{mg}$ was used. The experiments were performed under non-isothermal conditions with constant heating rates $(8,15,25$ or $35 \mathrm{~K} / \mathrm{min})$ in the temperature range from the ambient to $1723 \mathrm{~K}$. During the experiments, the sample was protected from oxidation by argon gas with a flow rate of $20 \mathrm{ml} / \mathrm{min}$. Bearing in mind that chromium has very high affinity to oxygen at high temperatures, the argon gas (purity $\geq 99.999 \%$ ) has been further purified by passing through silica gel, ascarite, copper turnings (main- 
tained at $873 \mathrm{~K}$ ) and magnesium chips (maintained at 773 $\mathrm{K})$ to decrease the traces of moisture, $\mathrm{CO}_{2}$ and oxygen in the argon gas. In the TGA experiments the mass loss of the sample was recorded as a function of time to the accuracy level of $1 \mu \mathrm{g}$. The reduction degree " $X$ " can be defined as:

$$
\begin{aligned}
& X=\frac{\text { Cumulative oxygen in the reaction off }- \text { gas }}{\text { Oxygen bounded to } \mathrm{FeCr}_{2} \mathrm{O}_{4}} \\
& \approx \frac{m_{0}-m_{t}}{m_{0} \times \mathrm{F} \times \frac{4 \times M_{\mathrm{CO}}}{M_{\mathrm{FeCr} 2 \mathrm{O} 4}}}
\end{aligned}
$$

Where $X$ denotes the reduction degree, $m_{0}$ the initial mass of the sample $(\mathrm{mg}), m_{t}$ the mass of the sample at time $t(\mathrm{mg})$, $F$ the mass percentage of $\mathrm{FeCr}_{2} \mathrm{O}_{4}$ in the original sample, $M_{C O}$ the molar mass of $\mathrm{CO}(\mathrm{g} / \mathrm{mol})$, and $M_{\mathrm{FeCr} 2 \mathrm{O} 4}$ the molar mass of $\mathrm{FeCr}_{2} \mathrm{O}_{4}(\mathrm{~g} / \mathrm{mol})$.

In order to characterize the state of reduction at different stages of the reduction process, another set of experiments was carried out in the SETARAM TGA-24 double-furnace unit. Samples with a mass of $150 \pm 1 \mathrm{mg}$ of the testing sample described above were heated at a heating rate of $15 \mathrm{~K} / \mathrm{min}$ to the temperature at which around $25 \mathrm{wt} \%$, 50 wt. $\%, 75$ wt. $\%$, or 95 wt. $\%$ of the reduction progress was perceived. The samples were then cooled at a cooling rate of $70 \mathrm{~K} / \mathrm{min}$ to room temperature. During heating and cooling, the samples were protected by argon gas purified as described earlier. The final reaction degree $X$ was determined by measuring the mass change of the sample before and after each experiment. These samples are referred to as "fractional reduced samples". The sections of the fractional reduced samples were analyzed by Scanning Electron Microscope equipped with Energy-Dispersive Spectroscopy (SEM/EDS). The samples were then crushed and subjected to X-Ray powder Diffraction (XRD) analysis. The XRD data were collected using $\mathrm{Cu}-\mathrm{K} \alpha$ radiation in the $2 \theta$ range of $15^{\circ}-85^{\circ}$ using a $0.017^{\circ}(2 \theta)$ step size and 36 second count time. Graphite in the sample was used as the internal reference. Several standard tests were used to check the accuracy of the XRD measurements.

Some selected TGA experiments were repeated to confirm the reproducibility, and it is also confirmed that the TGA data recorded by Netzsch 449C and SETARAM TGA24 double-furnace showed good agreement with each other.

\section{Results}

\subsection{Non-isothermal Reduction of $\mathrm{FeCr}_{2} \mathrm{O}_{4}$}

The TGA, DSC and DTG (differential form of the TGA curve, which indicates mass change rate) curves for the reduction of $\mathrm{FeCr}_{2} \mathrm{O}_{4}$ in sample $\mathrm{S} 1$ and sample $\mathrm{S} 5$ under non-isothermal conditions (heating rate $15 \mathrm{~K} / \mathrm{min}$ ) are shown in Figs. 2(a) and 2(b), respectively. For sample S1, it is seen that the mass loss of the sample starts at around $1300 \mathrm{~K}$ and is completed at around $1673 \mathrm{~K}$. The observed mass loss percentage, $40.03 \%$, closely approximates the theoretical value, $39.77 \%$, based on the overall reaction shown in Eq. (10), and the difference is probably due to experimental error. The excellent correlation between the shapes of DSC and DTG curves indicates that the reduction process is endothermic. The sharp endothermic peak
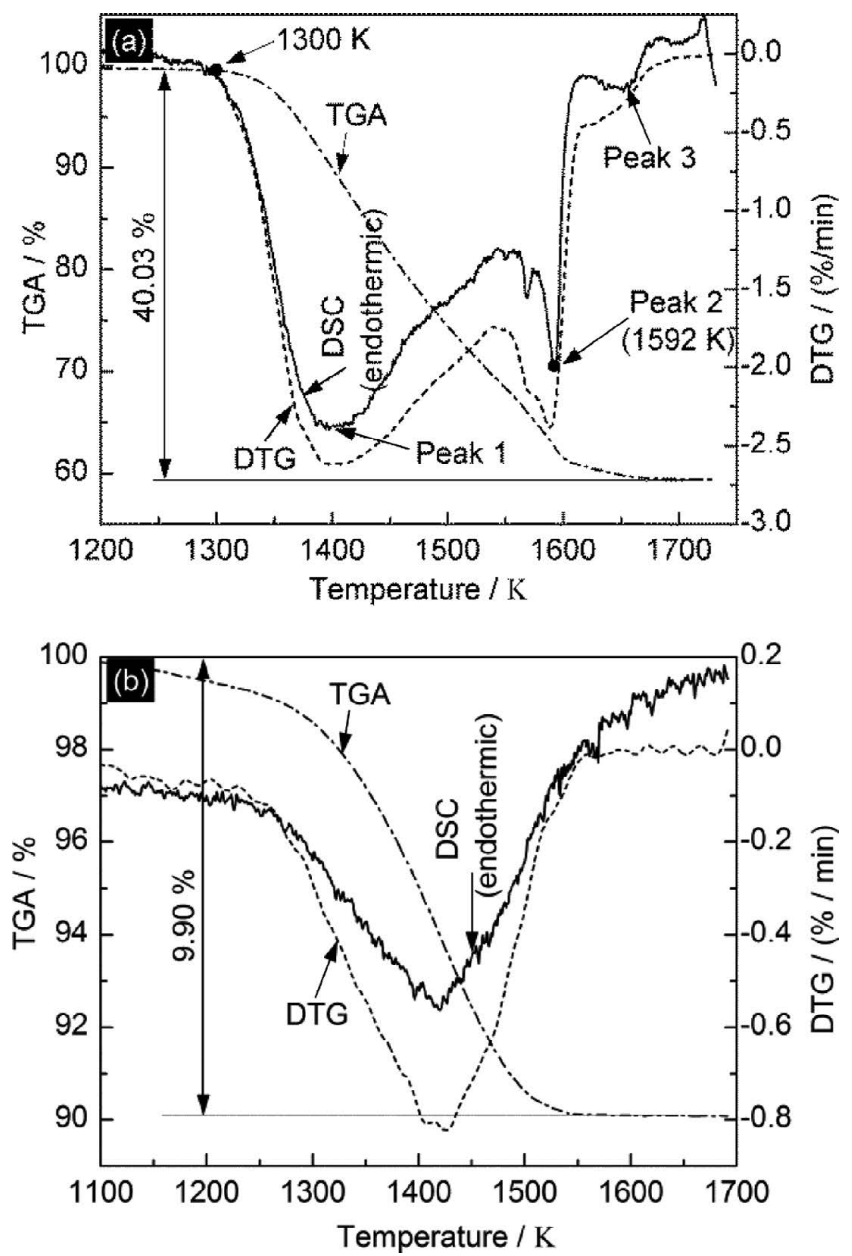

Fig. 2. TGA/DSC/DTG curves for (a) sample $\mathrm{S} 1$ (no iron addition) and (b) sample S5 (80 wt.\% iron addition) under nonisothermal conditions with heating rate $15 \mathrm{~K} / \mathrm{min}$ (arbitrary units for the DSC signals).

at $1592 \mathrm{~K}$ indicates the formation of a liquid phase, and this is further verified by the $\mathrm{Fe}-\mathrm{Cr}-\mathrm{C}$ phase diagram. The multi-peak characteristic of the DTG curve suggests that the reduction of $\mathrm{FeCr}_{2} \mathrm{O}_{4}$ without iron powder addition (sample $\mathrm{S} 1)$ might go through several steps.

In the case of sample S5, it is seen that mass loss of the sample starts at around $1150 \mathrm{~K}$ and completes at around $1550 \mathrm{~K}$. The observed mass loss percentage, 9.90\%, is close to the theoretical value, $9.51 \%$, based on the overall reaction shown in Eq. (10). Besides the experimental error, the fact that the observed mass loss value being higher than the theoretical value and the starting temperature of the reduction being lower than that of sample $\mathrm{S} 1$ is probably due to the presence of traces of iron oxide, which could be from the added iron powder. Further, for this sample there is no evidence of the formation of any liquid phase in the temperature range investigated. The single-peak characteristic of the DTG curve suggests that the reduction of $\mathrm{FeCr}_{2} \mathrm{O}_{4}$ with up to $80 \mathrm{wt} \%$ iron addition (sample S5) might go through a single step.

\subsection{Effect of Iron Powder Addition on the Carbothermic Reduction of $\mathrm{FeCr}_{2} \mathrm{O}_{4}$}

To evaluate the effect of iron addition on the reduction of $\mathrm{FeCr}_{2} \mathrm{O}_{4}$, the reduction curves for the samples with various 
amounts of iron addition (samples S1 to S5) were drawn as reduction degree $X$ (the mass loss, probably, due to the presence of iron oxide was not counted in the reduction degree $X$ ) versus time $t$ curves and plotted in one figure, viz. Fig. 3. Iron addition is seen to have a pronounced impact

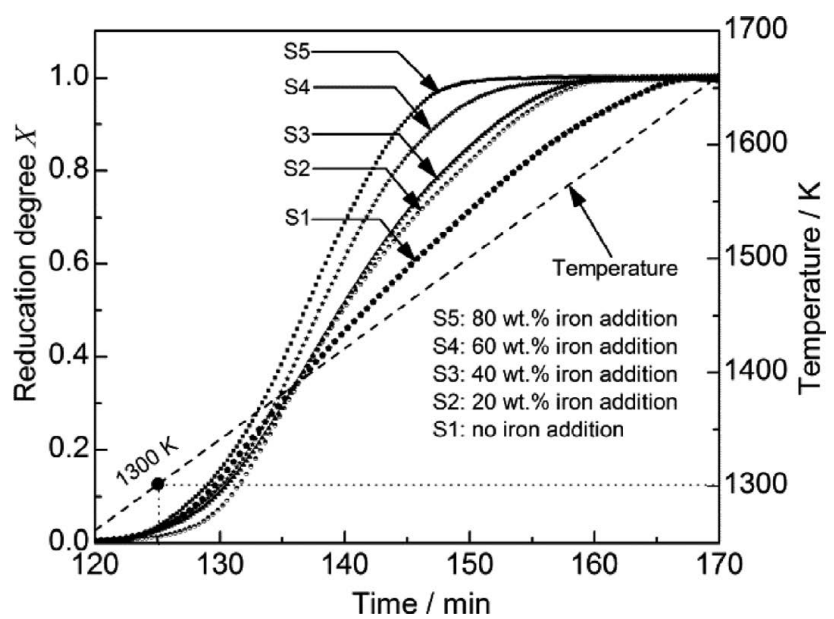

Fig. 3. Effect of iron addition on the carbothermic reduction of $\mathrm{FeCr}_{2} \mathrm{O}_{4}$ under non-isothermal conditions (heating rate 8 $\mathrm{K} / \mathrm{min}$ ). on the reduction of $\mathrm{FeCr}_{2} \mathrm{O}_{4}$ : (1) iron addition increases the reduction rate, especially at higher temperatures and in the samples with higher amount of iron addition; (2) iron addition reduces the temperature that is needed to complete the reduction, i.e., iron addition shortens the time needed for the reduction. These results clearly indicate that the presence of iron in the $\mathrm{FeCr}_{2} \mathrm{O}_{4}$-graphite mixture enhances the reduction of $\mathrm{FeCr}_{2} \mathrm{O}_{4}$, and the enhancing effect increases when increased amounts of iron powder are added.

\subsection{XRD Results}

The XRD analysis results for the fractional reduced samples of S1, S3 and S5 are shown in Fig. 4. For sample $\mathrm{S} 1$ it is found that $\mathrm{Cr}_{2} \mathrm{O}_{3}$ appears as an intermediate phase during the reduction, as it is formed in the initial stage of reduction and consumed in the later stage of reduction. It is also found that a mixed carbide, $(\mathrm{Cr}, \mathrm{Fe})_{7} \mathrm{C}_{3}$, is formed during the reduction and the as-formed $(\mathrm{Cr}, \mathrm{Fe})_{7} \mathrm{C}_{3}$ is consumed in the later stage of reduction. This is evidenced by the observation from the XRD patterns that the intensities of $(\mathrm{Cr}, \mathrm{Fe})_{7} \mathrm{C}_{3}$ peaks become weaker as the reduction proceeds to a high degree (sample $\mathrm{S} 1, X=0.96$ ). At the end of the reduction, the products in the case of sample $\mathrm{S} 1$ are mainly $\mathrm{Fe}-\mathrm{Cr}-\mathrm{C}$ alloy and $(\mathrm{Cr}, \mathrm{Fe})_{7} \mathrm{C}_{3}$. For sample $\mathrm{S} 3$, the phases
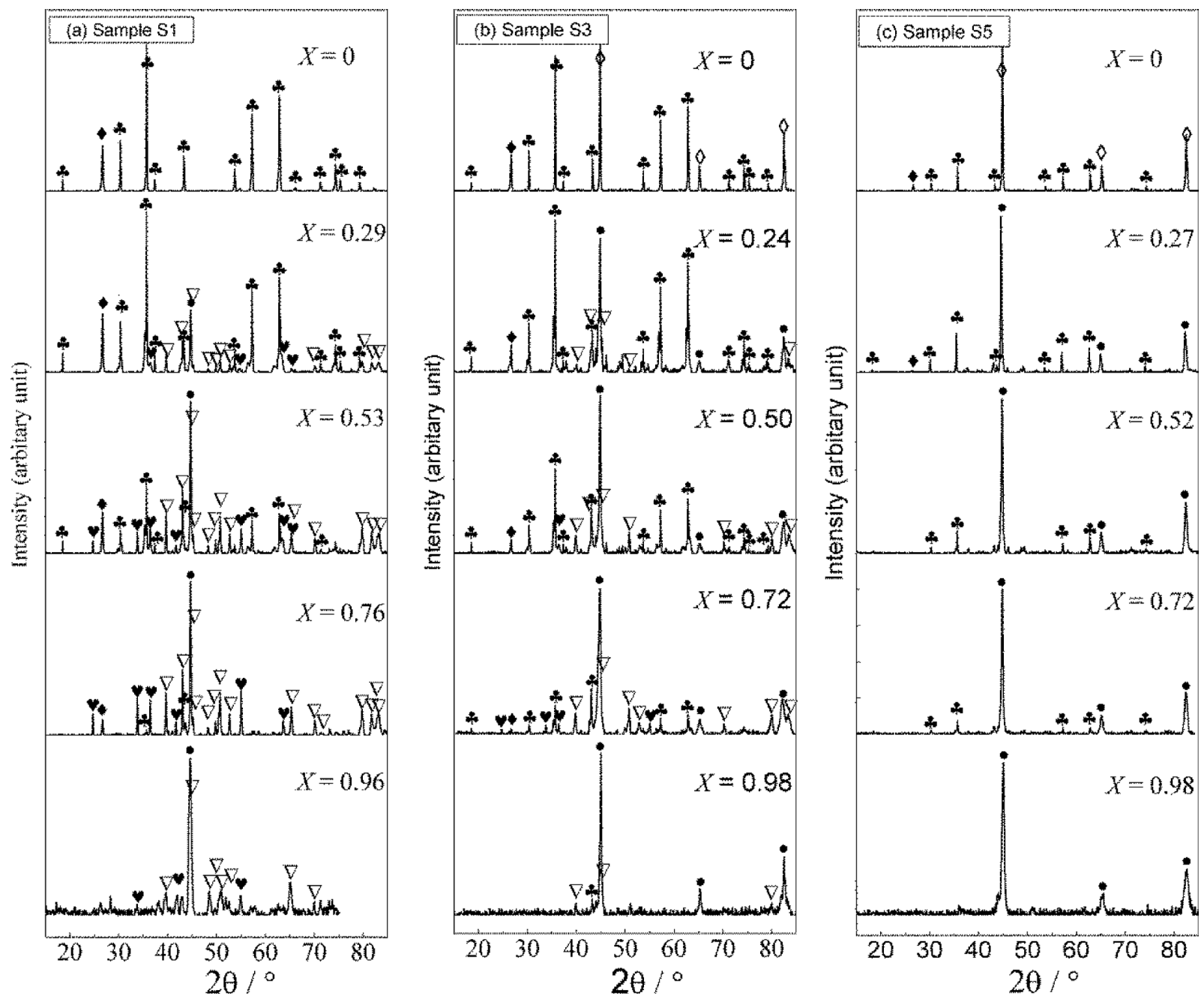

Fig. 4. XRD patterns for (a) sample $\mathrm{S} 1$ (no iron addition), (b) sample S3 (40 wt.\% iron addition) and (c) sample S5 (80 wt.\% iron addition) at various reduction degree $X\left[\boldsymbol{\iota}-\mathrm{FeCr}_{2} \mathrm{O}_{4} ; \bullet\right.$-graphite; $\bullet-\mathrm{Cr}_{2} \mathrm{O}_{3} ; \diamond-\mathrm{Fe} ; \bullet-\mathrm{Fe}-\mathrm{Cr}-\mathrm{C}$ alloy; $\left.\nabla-(\mathrm{Cr}, \mathrm{Fe})_{7} \mathrm{C}_{3}\right]$. 
formed at different stages of reduction are almost the same as that of sample $\mathrm{S} 1$. However, the intensities of $\mathrm{Cr}_{2} \mathrm{O}_{3}$ and $(\mathrm{Cr}, \mathrm{Fe})_{7} \mathrm{C}_{3}$ peaks are weaker than those observed in the case of sample $\mathrm{S} 1$. For sample $\mathrm{S} 5$, neither $\mathrm{Cr}_{2} \mathrm{O}_{3}$ nor $(\mathrm{Cr}, \mathrm{Fe})_{7} \mathrm{C}_{3}$ can be detected during the whole course of reduction, the product being $\mathrm{Fe}-\mathrm{Cr}-\mathrm{C}$ alloy.

Figure 5 shows the diffraction peaks for graphite, $\mathrm{Fe}-$ $\mathrm{Cr}-\mathrm{C}$ alloy phase and mixed carbide $(\mathrm{Cr}, \mathrm{Fe})_{7} \mathrm{C}_{3}$. For graphite, the diffraction peaks in different samples and at different stages of the reduction are unaltered, further confirming that graphite can be regarded as the internal reference. For Fe$\mathrm{Cr}-\mathrm{C}$ alloy, the diffraction peaks get slightly shifted towards a low $(2 \theta)$ diffraction angle as the reduction proceeds. This is due to the interstitial dissolution of carbon in the iron and substitutional dissolution of chromium (the atom radius of $\mathrm{Cr}$ is higher than that of $\mathrm{Fe}$ atom, $1.28 \AA$ for $\mathrm{Cr}$ as compared to $1.26 \AA$ for $\mathrm{Fe}^{31)}$ ) in the iron, both of which increase the lattice parameter of the alloy phase. For the mixed carbide, $(\mathrm{Cr}, \mathrm{Fe})_{7} \mathrm{C}_{3}$, the diffraction peaks also get shifted towards a low $(2 \theta)$ diffraction angle as the reduction proceeds. This is due to the substitutional dissolution of chromium into $(\mathrm{Cr}, \mathrm{Fe})_{7} \mathrm{C}_{3}$. In Fig. 5 the Bragg positions of several reference materials ( $\mathrm{Fe}, \mathrm{Cr}, \mathrm{Fe}_{7} \mathrm{C}_{3}$ and $\mathrm{Cr}_{7} \mathrm{C}_{3}$ ) are also given. It is seen that the Bragg positions of the diffraction peaks of the mixed carbide formed in sample S3 are closer to the Bragg position of $\mathrm{Fe}_{7} \mathrm{C}_{3}$ than that of sample $\mathrm{S} 1$, and the Bragg positions of the diffraction peaks of $\mathrm{Fe}-\mathrm{Cr}-\mathrm{C}$ alloy formed in sample $\mathrm{S} 3$ and sample $\mathrm{S} 5$ are closer to pure Fe than that in sample $\mathrm{S} 1$, indicating that the as-formed mixed carbide in sample S3 and the Fe-Cr-C alloy formed in sample S3 and $\mathrm{S} 5$ are more dilute with respect to chromium due to the addition of respectively $40 \mathrm{wt} . \%$ and $80 \mathrm{wt} \%$ iron powder in sample S3 and sample S5. It is also seen that, generally, the diffraction peaks of $\mathrm{Fe}-\mathrm{Cr}-\mathrm{C}$ alloy phase become broader and broader as the reduction proceeds to an increasingly higher degree, and this may be due to the inhomogeneous distribution or dissolution of chromium and carbon in the alloy phase.

\subsection{SEM/EDS Results}

Figure 6 shows the SEM micrographs of the sections of some fractional reduced samples. For sample S1 the unreduced particles are surrounded by dense layers of $\mathrm{Fe}-\mathrm{Cr}-\mathrm{C}$ alloy and $(\mathrm{Cr}, \mathrm{Fe})_{7} \mathrm{C}_{3}$ (indicated by EDS analysis and confirmed by XRD analysis). For sample S3 and sample S5, the unreduced particles are mainly surrounded by porous and dendritic $\mathrm{Fe}-\mathrm{Cr}-\mathrm{C}$ alloy particles. According to the EDS analysis results, the chromium concentration in $\mathrm{Fe}-\mathrm{Cr}-\mathrm{C}$ alloy for these three different samples has the following order: sample $\mathrm{S} 1>$ sample $\mathrm{S} 3>$ sample S5.

\section{Discussion}

\subsection{The Enhancing Effect of Iron Addition on the Reduction of $\mathrm{FeCr}_{2} \mathrm{O}_{4}$}

The iron addition into the $\mathrm{FeCr}_{2} \mathrm{O}_{4}$-graphite mixture would lead to a decrease in the contact area between $\mathrm{FeCr}_{2} \mathrm{O}_{4}$ particles and graphite particles. The reduction, however, is found to be enhanced with iron powder addition in the $\mathrm{FeCr}_{2} \mathrm{O}_{4}$-graphite mixture. The enhancing effect of iron addition on the reduction of component $\mathrm{Cr}_{2} \mathrm{O}_{3}$, on one hand, can be attributed to the presence of iron particles which become carbon carriers (due to the dissolution of carbon into iron), enhancing the direct reactions and, on the other hand, to the catalytic effect of iron on the Boudouard reaction, ${ }^{1,33)}$ enhancing the indirect reactions. However,

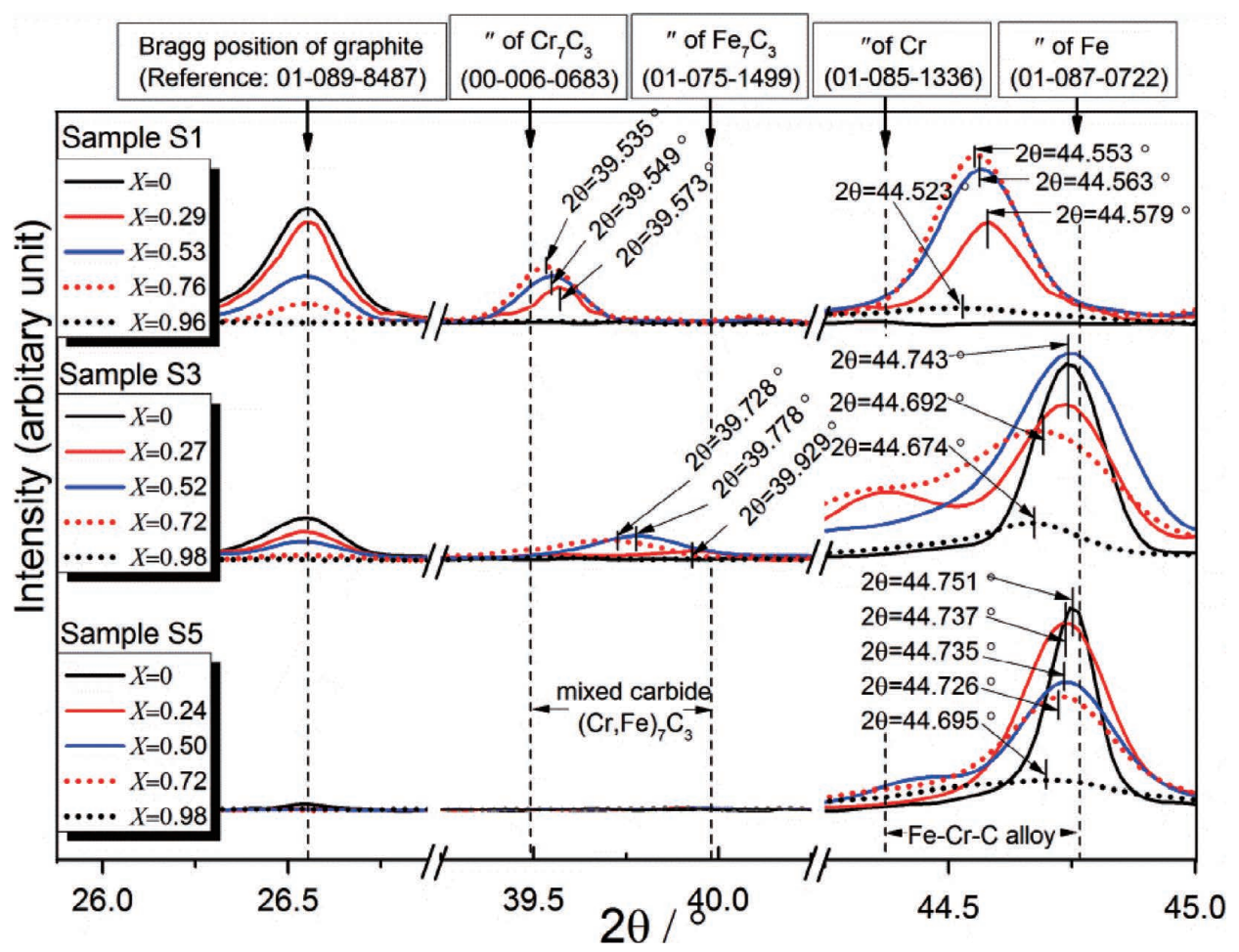

Fig. 5. Selected diffraction peaks of graphite, $(\mathrm{Cr}, \mathrm{Fe})_{7} \mathrm{C}_{3}$ and $\mathrm{Fe}-\mathrm{Cr}-\mathrm{C}$ alloy for sample $\mathrm{S} 1$ (no iron addition), sample $\mathrm{S} 3$ (40 wt.\% iron addition) and sample S5 (80 wt.\% iron addition) at various stages of reduction (Bragg positions for the references are derived from ICDD PDF-2 database ${ }^{32)}$ ). 
these explanations may have to be ruled out, as: (1) metallic oxide-carbon reaction is believed to proceed overwhelmingly via indirect reactions, ${ }^{9,22-27)}$ (2) the Boudouard reaction is likely to be very fast in present experimental temperature range $1300-1600 \mathrm{~K},{ }^{34)}$ during which most part of the reduction takes place. Okumura et al. ${ }^{11)}$ and Shimoo et al. ${ }^{18)}$ investigated the reduction of $\mathrm{Cr}_{2} \mathrm{O}_{3}$ in the presence of $\mathrm{Fe}_{2} \mathrm{O}_{3}(\mathrm{Cr} / \mathrm{Fe}=1: 1)$. They all found that the presence of $\mathrm{Fe}_{2} \mathrm{O}_{3}$ accelerated the reduction of $\mathrm{Cr}_{2} \mathrm{O}_{3}$, and they attributed this to the formation of carbon-containing molten iron. In
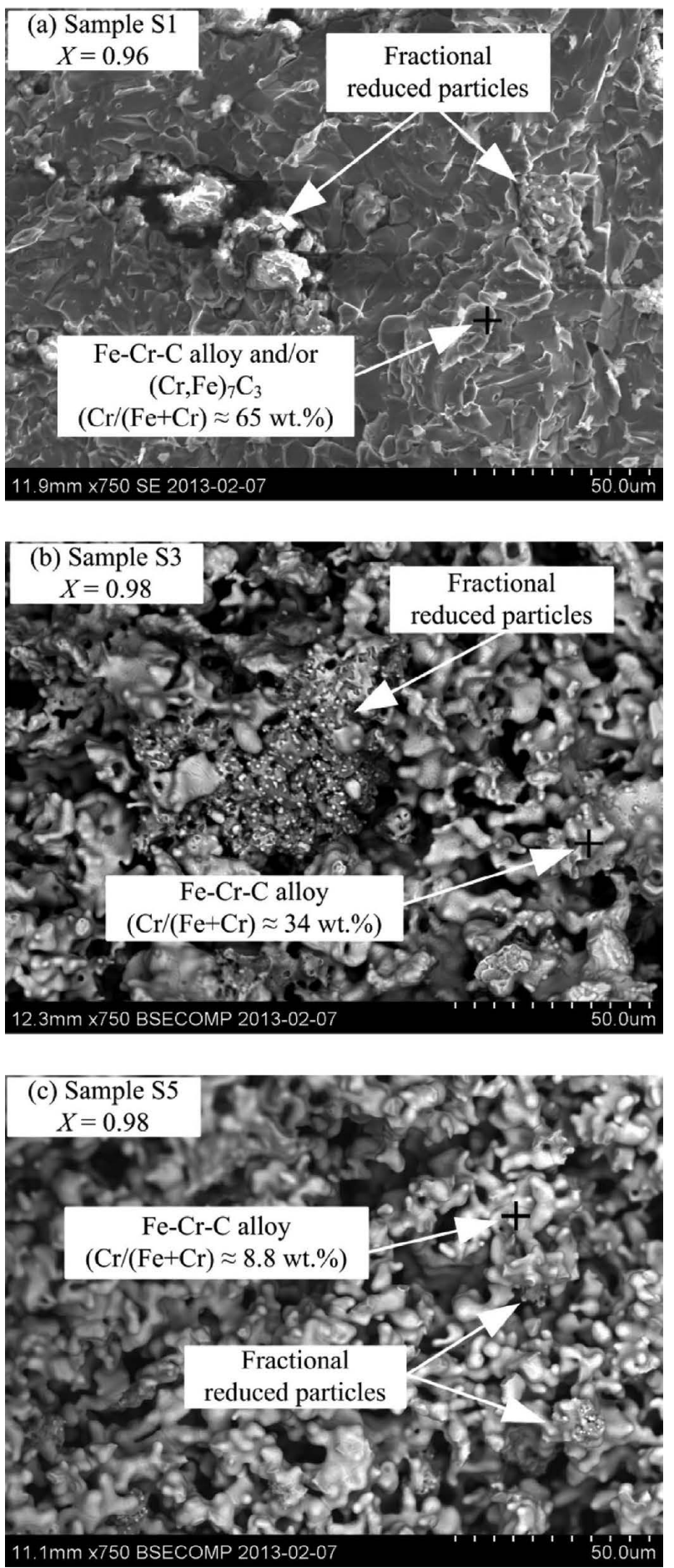

Fig. 6. SEM (back scattered electron) micrographs and EDS analysis of the selected areas for the fractional reduced samples of (a) sample S1 (no iron addition), (b) sample S3 (40 wt.\% iron addition) and (c) sample S5 (80 wt.\% iron addition). the present investigation it was found that the enhancement of the reaction rate started at a temperature of around 1300 $\mathrm{K}$ (as shown in Fig. 3). According to $\mathrm{Fe}-\mathrm{Cr}-\mathrm{C}$ phase diagram, a molten metallic phase is not likely to form in this temperature region. Further, the DSC curve for sample S5, as shown in Fig. 2(b), shows no evidence of the formation of a liquid phase during the reduction of $\mathrm{FeCr}_{2} \mathrm{O}_{4}$. Ma et al. investigated the solid-state reduction in the $\mathrm{Fe}_{2} \mathrm{O}_{3}-\mathrm{NiO}-$ $\mathrm{Cr}_{2} \mathrm{O}_{3}-\mathrm{C}$ system. ${ }^{35)}$ They found that $\mathrm{Fe}_{2} \mathrm{O}_{3}$ enhanced the complete reduction of $\mathrm{Cr}_{2} \mathrm{O}_{3}$ at a temperature lower than that required for reducing pure $\mathrm{Cr}_{2} \mathrm{O}_{3}$, and they attributed this enhancing effect to the formation of transitional compound ' $\mathrm{FeCr}_{2} \mathrm{O}_{4}$ '. This explanation may also have to be ruled out, since the metallic iron addition would not lead to the formation of $\mathrm{FeCr}_{2} \mathrm{O}_{4}$ as observed in the present work.

In this study, the enhancing effect of iron addition on the carbothermic reduction of $\mathrm{FeCr}_{2} \mathrm{O}_{4}$ is attributed to the decrease in the activity of chromium formed due to the in situ dissolution of chromium into iron and mixed carbide $(\mathrm{Cr}, \mathrm{Fe})_{7} \mathrm{C}_{3}$. The $\mathrm{Cr}$ dissolution is supported by the XRD observation shown in Fig 5. Iron is likely to enhance $\mathrm{Cr}$ dissolution due to the presence of active centers on the surface of the iron particles enabling a faster dissolution of chromium. Figure 6 shows the presence of iron in the vicinity of unreduced particles. In this case, iron will act as a sink for the chromium formed by reduction. Higher amounts of added iron powder will enhance this due to a significant lowering of the activity of chromium in the alloy, contributing thereby to the driving force for the reaction. It is noted that some carbon will also dissolve into the iron, and the dissolved carbon in the $\mathrm{Fe}-\mathrm{Cr}$ solid solution will cause a further decrease in the activity of $\mathrm{Cr}^{36}{ }^{36}$ The present reasoning is supported by other, earlier investigations. ${ }^{37-39)}$

\subsection{Phase Evolution during the Reduction and Reduc- tion Mechanism}

According to the XRD results shown in Fig. 4, the phase evolution for different samples can be evaluated. For sample $\mathrm{S} 1, \mathrm{Cr}_{2} \mathrm{O}_{3}$ and $\mathrm{FeCr}_{2} \mathrm{O}_{4}$ were found to coexist. This indicates that the reaction corresponding to Eq. (4) takes place in the initial stage of the reduction. In the later stage $\mathrm{Cr}_{2} \mathrm{O}_{3}$ will be reduced, and it is quite plausible that the reaction corresponding to Eq. (5) takes place, since $(\mathrm{Cr}, \mathrm{Fe})_{7} \mathrm{C}_{3}$ is found to be the reduction product. The as-formed $(\mathrm{Cr}, \mathrm{Fe})_{7} \mathrm{C}_{3}$ is found to be consumed in the later stage of the reduction. This consumption of $(\mathrm{Cr}, \mathrm{Fe})_{7} \mathrm{C}_{3}$ can either be attributed to the dissolution of $(\mathrm{Cr}, \mathrm{Fe})_{7} \mathrm{C}_{3}$ into $\mathrm{Fe}-\mathrm{Cr}-\mathrm{C}$ alloy at higher temperatures, or be a consequence of reaction corresponding to Eq. (7) taking place in the later stage of the reduction when free carbon in the sample becomes scarce. The sequential reactions corresponding to Eqs. (4), (5) and (7) may explain well the multi-peak characteristic of the DTG curve for sample $\mathrm{S} 1$ (as shown in Fig. 2(a)). For sample S5, neither $\mathrm{Cr}_{2} \mathrm{O}_{3}$ nor $(\mathrm{Cr}, \mathrm{Fe})_{7} \mathrm{C}_{3}$ are found during the whole course of reduction. This may indicate that the reactions corresponding to Eqs. (4) and (6) dominate the reduction and take place simultaneously. The simultaneous reactions corresponding to Eqs. (4) and (6) may explain well the single-peak characteristic of the DTG curve for sample S5 (as shown in Fig. 2(b)). For sample S3, the phase evolution during the reduction is generally the same as that of sample 
S1. However, reactions (4) and (6) are likely to proceed with increased rate due to the addition of iron. The $\mathrm{Fe}-\mathrm{Cr}-\mathrm{C}$ equilibrium phase diagrams at two evaluated temperatures are shown in Fig. 7. The equilibrium compositions of sample S1, sample S3 and sample S5 after complete reduction are depicted as points $\mathrm{C}_{\mathrm{S} 1}, \mathrm{C}_{\mathrm{S} 3}$ and $\mathrm{C}_{\mathrm{S} 5}$, respectively. It is seen that final phases observed by XRD analyses correlate very well with the phase diagrams. The absence of $\mathrm{Cr}_{2} \mathrm{O}_{3}$ during the reduction of $\mathrm{FeCr}_{2} \mathrm{O}_{4}$ in sample S5 suggests that the reduction might go through a single step, and the absence of $(\mathrm{Cr}, \mathrm{Fe})_{7} \mathrm{C}_{3}$ may suggest a fast dissolution of the product $\left(\mathrm{FeCr}_{2}\right.$, reduced from $\left.\mathrm{FeCr}_{2} \mathrm{O}_{4}\right)$ into the iron added, since the accumulation of the product could otherwise lead to the formation of $(\mathrm{Cr}, \mathrm{Fe})_{7} \mathrm{C}_{3}$.

\subsection{Kinetic Analysis}

In the present study, under non-isothermal conditions, the reduction of $\mathrm{FeCr}_{2} \mathrm{O}_{4}$ without iron addition (sample $\mathrm{S} 1$ ) is likely to consist of three different steps, namely: reduction of $\mathrm{FeCr}_{2} \mathrm{O}_{4}$ to $\mathrm{Cr}_{2} \mathrm{O}_{3}$, reduction of $\mathrm{Cr}_{2} \mathrm{O}_{3}$ to $(\mathrm{Cr}, \mathrm{Fe})_{7} \mathrm{C}_{3}$ and the reduction step in the presence of liquid phase. It is quite likely that these reduction steps overlap to some extent and

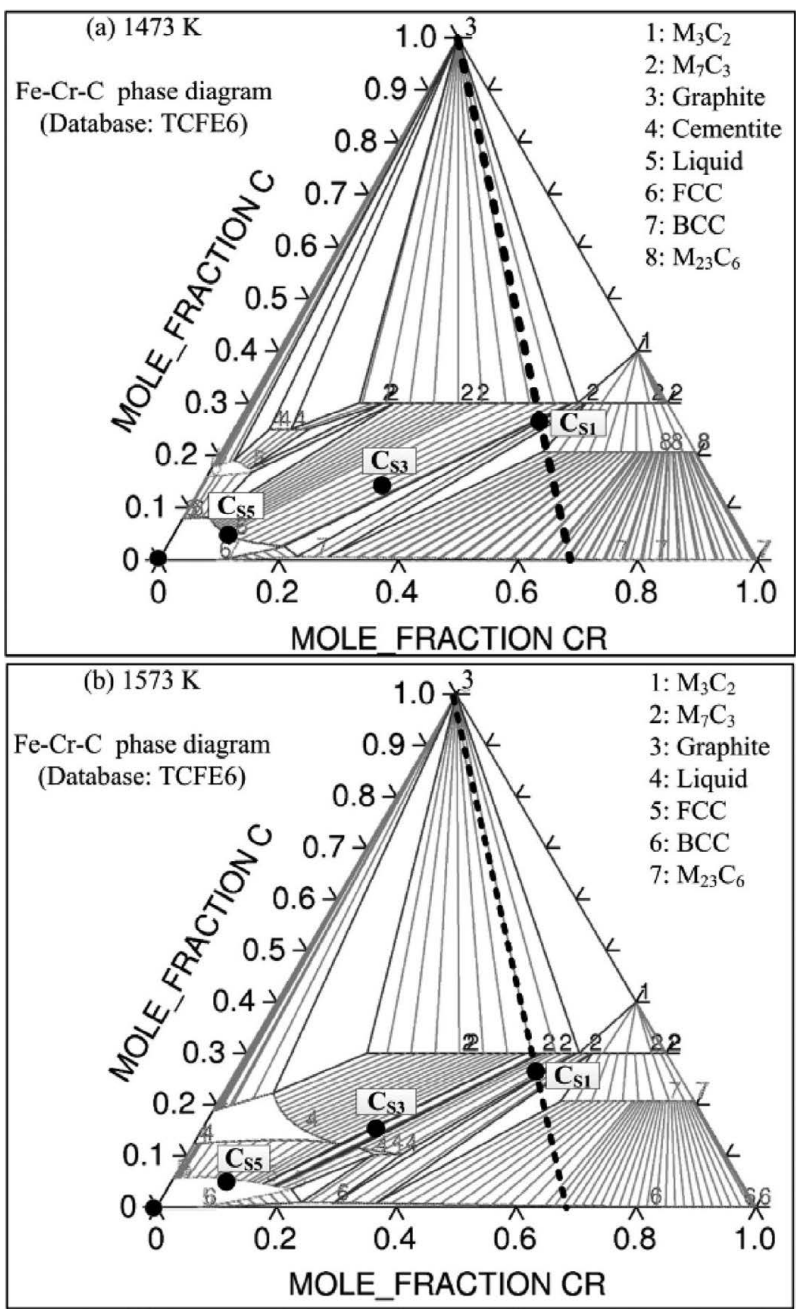

Fig. 7. $\mathrm{Fe}-\mathrm{Cr}-\mathrm{C}$ phase diagrams at (a) $1473 \mathrm{~K}$, and (b) $1573 \mathrm{~K}$. (The figures are derived from TCFE database of software package Thermo-calc; ${ }^{40)} \mathrm{C}_{\mathrm{S} 1}, \mathrm{C}_{\mathrm{S} 3}$, and $\mathrm{C}_{\mathrm{S} 5}$ are the equilibrium composition points of sample $\mathrm{S} 1$ (no iron addition), $\mathrm{S} 3$ (40 wt.\% iron addition) and S5 (80 wt.\% iron addition), respectively, after complete reduction). are governed by different kinetic mechanisms. ${ }^{3,4,6,10)}$ The iron addition changes the reduction mechanism and, as discussed earlier, the reduction of $\mathrm{FeCr}_{2} \mathrm{O}_{4}$ with 80 wt.\% iron addition (sample S5) is quite likely to be a single step reaction. In this paper, sample S5 is selected for kinetic analysis.

To propose a possible kinetic mechanism, the following assumptions are made according to the aforementioned: (1) an indirect reaction $\left(\mathrm{FeCr}_{2} \mathrm{O}_{4} / \mathrm{CO}\right.$ reduction) mechanism prevails during the reduction; (2) kinetics of the Boudouard reaction $\left(\mathrm{C} / \mathrm{CO}_{2}\right.$ reaction $)$ is much faster than the reduction of $\mathrm{FeCr}_{2} \mathrm{O}_{4}$ by $\mathrm{CO}$, and the Boudouard reaction is non-ratecontrolling. Then, the reduction of $\mathrm{FeCr}_{2} \mathrm{O}_{4}$ in sample $\mathrm{S} 5$ can be treated as pseudo gas/solid reaction, which can be represented as follows:

$$
\mathrm{FeCr}_{2} \mathrm{O}_{4}(\mathrm{~s})+4 \mathrm{CO}(\mathrm{g}) \rightarrow \text { alloy }(\mathrm{s})+4 \mathrm{CO}_{2}(\mathrm{~g}) \ldots . .
$$

It is noted that the 'alloy' in Eq. (12) stands for $\mathrm{Fe}-\mathrm{Cr}-\mathrm{C}$ solid solution with different compositions at different stages of reduction and the generated $\mathrm{CO}_{2}$ gas is converted to $\mathrm{CO}$ gas immediately via the Boudouard reaction. The ratecontrolling step for reaction (12) can be one or more of the following steps:

(a) Gas-solid chemical reaction at the $\mathrm{FeCr}_{2} \mathrm{O}_{4}$ /iron interface; (b) Dissolution of $\mathrm{FeCr}_{2}$ into the iron particles (or the alloy particles in the later stage);

(c) Inward diffusion of $\mathrm{CO}$ and outward diffusion of $\mathrm{CO}_{2}$ through the product layer;

(d) Nucleation at the surface of $\mathrm{FeCr}_{2} \mathrm{O}_{4}$ particle.

From the SEM micrograph shown in Fig. 6(c), it is seen that the product formed is quite porous. Therefore, step (c) should be excluded, since the diffusion of gas species through such a porous product should be quite fast. In sample S5 as high as $80 \mathrm{wt} . \%$ of iron powder is added and mixed with $\mathrm{FeCr}_{2} \mathrm{O}_{4}$. The presence of iron powder in the vicinity of $\mathrm{FeCr}_{2} \mathrm{O}_{4}$ should provide direct nucleation sites for the nascent reduction product $\left(\mathrm{FeCr}_{2}\right)$. Therefore, step (d) is also assumed to be non-rate-controlling. It has been noted by some other investigators ${ }^{37,38)}$ that the reduction of chromium oxide in the presence of VI group metallic powder could be controlled by chemical reaction in the initial stage and by diffusional dissolution of chromium in the metallic particles in the later stage, which are comparable to the present case. Hence, in the present analysis, it is considered that the rate controlling step could be either step (a) or step (b). However, it is also reasonable to assume that the reaction corresponding to Eq. (12) has a mixed control mechanism combining the chemical reaction at the surface of $\mathrm{FeCr}_{2} \mathrm{O}_{4}$ particles and diffusional dissolution of $\mathrm{FeCr}_{2}$ into the iron/ alloy particles. The mixed control reaction mechanism in the present case can be understood as follows: a fast chemical reaction rate will increase the concentration of $\mathrm{FeCr}_{2}$ at the surface of iron particle and thus thermodynamically retard the reduction; a slow chemical reaction rate will decrease the concentration of $\mathrm{FeCr}_{2}$ at the surface of the iron/alloy particle by allowing a longer dwelling time for diffusional dissolution of $\mathrm{FeCr}_{2}$, and thus thermodynamically enhance the reduction. The proposed kinetic mechanisms will be checked by the present non-isothermal experimental data and confirmed by the isothermal experimental data in the future. 


\section{Conclusions}

In this paper, carbothermic reduction of synthetic iron chromite $\left(\mathrm{FeCr}_{2} \mathrm{O}_{4}\right)$ with/without iron powder addition was investigated by Thermogravimetric Analysis in argon atmosphere. Fractional reduced samples were examined by SEM/EDS and XRD analyses, and the reduction process was evaluated by both thermodynamic and kinetic analyses. The conclusions can be summarized as follows:

(1) Carbothermic reduction of $\mathrm{FeCr}_{2} \mathrm{O}_{4}$ without iron powder addition is a quite complex process, which is likely to consist of three different reduction steps under present experimental conditions; $\mathrm{Cr}_{2} \mathrm{O}_{3}$ was detected as the intermediate during the reduction, $\mathrm{Fe}-\mathrm{Cr}-\mathrm{C}$ alloy and mixed carbide $(\mathrm{Cr}, \mathrm{Fe})_{7} \mathrm{C}_{3}$ were determined to be the final reduction products

(2) Neither $\mathrm{Cr}_{2} \mathrm{O}_{3}$ nor $(\mathrm{Cr}, \mathrm{Fe})_{7} \mathrm{C}_{3}$ was detected during the reduction of $\mathrm{FeCr}_{2} \mathrm{O}_{4}$ with 80 wt.\% iron addition, $\mathrm{Fe}-\mathrm{Cr}-\mathrm{C}$ alloy was determined to be the only reduction products; it is quite likely that, in this case, the reduction of $\mathrm{FeCr}_{2} \mathrm{O}_{4}$ is a single-stage process.

(3) The iron powder addition enhances the reduction of the $\mathrm{FeCr}_{2} \mathrm{O}_{4}$, and the enhancing effect increases when increasing amounts of iron powder are added. This effect is attributed to the in situ dissolution of chromium into iron and mixed carbide $(\mathrm{Cr}, \mathrm{Fe})_{7} \mathrm{C}_{3}$, which can decrease the activity of the nascent chromium.

(4) The presence of metallic iron in the reduction process of $\mathrm{FeCr}_{2} \mathrm{O}_{4}$ has a pronounced impact on the reduction kinetics. The kinetic analysis on the reduction of $\mathrm{FeCr}_{2} \mathrm{O}_{4}$ with $80 \mathrm{wt} . \%$ iron addition suggests that the reduction reaction is likely to be either (a) chemical reaction at the surface of $\mathrm{FeCr}_{2} \mathrm{O}_{4}$ or (b) diffusional dissolution of the product $\left(\mathrm{FeCr}_{2}\right)$ into the iron/alloy particles or the mixed control of (a) and (b).

\section{Acknowledgement}

The authors wish to thank the Hugo Carlssons Foundation and CAMM, Centre of Advanced Mining and Metallurgy at Luleå University of Technology, for the financial support for this work. Professor Viswanathan Numi at Luleå University of Technology is gratefully acknowledged for useful discussions.

\section{REFERENCES}

1) H. G. Katayama and M. Tokuda: Tetsu-to-Hagané, 71 (1985), 1094.

2) H. G. Katayama and M. Tokuda: Tetsu-to-Hagané, 65 (1978), 331.

3) C. P. J. Van Vuuren, J. J. Bodenstein, M. Sciarone and P. Kestens: Proc. of INFACON 6, SAIMM, Johannesburg, (1992), 51.

4) N. S. Sundar Murti and V. Seshadri: Trans. Iron Steel Inst. Jpn., 22 (1982), 925.

5) Y.-1. Zhang, Y. Liu and W.-j. Wei: Int. J. Min. Met. Mater., 20 (2013), 931.

6) Y. Wang, L. Wang, J. Yu and K. C. Chou: J. Min. Metall. Sect. B Metall., 50 (2014), 15.

7) Y. Wang, L. Wang and K. C. Chou: J. Min. Metall. Sect. B Metall., 51 (2015), 17.

8) T. Mori, J. Yang and M. Kuwabara: ISIJ Int., 47 (2007), 1387.

9) R. J. Fruehan: Metall. Trans. B, 8 (1997), 429.

10) Q. Lin, R. Liu and N. Chen: J. Therm. Anal. Calorim., 58 (1999), 317.

11) K. Okumura, T. Sugimura, M. Kuwabara and M. Sano: Tetsu-toHagané, 90 (2004), 992.

12) H. G. Katayama, M. Tokuda and M. Ohtani: Tetsu-to-Hagané, 72 (1986), 1513.

13) Y. L. Ding and N. A. Warner: Thermochim. Acta, 292 (1997), 85.

14) P. Weber and R. H. Eric: Miner. Eng., 19 (2006), 318.

15) P. Weber and R. H. Eric: Metall. Mater. Trans. B, 24 (1993), 987.

16) P. Weber and R. H. Eric: Proc. INFACON 6, SAIMM, Johannesburg, (1992), 71

17) J. S. J. Van Deventer: Thermochim. Acta, 127 (1988), 25.

18) T. Shimoo, F. Mizutaki, S. Ando and H. Kimura: J. Jpn. Inst. Met., 52 (1988), 654.

19) M. Görnerup and H. Jacobsson: Proc. 55th Electric Furnace Conf., Iron and Steel Society, Chicago, (1997), 57.

20) M. Görnerup and A. K. Lahiri: Ironmaking Steelmaking, 25 (1998), 317.

21) M. Görnerup and A. K. Lahiri: Ironmaking Steelmaking, 25 (1998), 382.

22) M. I. El-Guindy and W. G. Davenport: Metall. Trans., 1 (1970), 1729.

23) Y. K. Rao: Metall. Trans., 2 (1971), 1439.

24) Y. Maru, Y. Kuramasu, Y. Awakura and Y. Kondo: Metall. Trans., 4 (1973), 2591.

25) N. S. Srinivasan and A. K. Lahiri: Metall. Trans. B, 8 (1977), 175.

26) R. Padilla and H. Y. Sohn: Metall. Trans. B, 10 (1979), 109.

27) S. K. Gupta, V. Rajakumar and P. Grieveson: Metall. Trans. B, 18 (1987), 713.

28) Y. Kashiwaya, M. Kanbe and K. Ishii: ISIJ Int., 41 (2001), 818.

29) C. W. Bale, E. Bélisle, P. Chartrand, S. A. Decterov, G. Eriksson, K. Hack, I. H. Jung, Y. B. Kang, J. Melançon, A. D. Pelton, C. Robelin and S. Petersen: Calphad, 33 (2009), 295.

30) X. Hu, H. Wang, L. Teng and S. Seetharaman: J. Min. Metall. Sect. B Metall., 49 (2013), 207.

31) N. N. Greenwood and A. Earnshaw: Chemistry of the Elements, 2nd ed., Elsevier Butterworth-Heinemann, Oxford, (1997), 1004.

32) International Centre for Diffraction Data: PDF-2 2003 Database Sets: Newton Square, PA, (2003).

33) E. T. Turkdogan and J. V. Vinters: Carbon, 10 (1972), 97.

$34)$ E. T. Turkdogan and J. V. Vinters: Carbon, 8 (1970), 39.

35) P. Ma, B. Lindblom and B. Björkman: Scand. J. Metall., 34 (2005), 22.

36) L. D. Teng, R. E. Aune, M. Selleby and S. Seetharaman: Metall. Mater. Trans. B, 36 (2005), 263.

37) G. V. Samsonov and T. K. Osipova: Sov. Powder Metall. Met. Ceram., 13 (1974), 257.

38) V. V. Skorokhod and L. I. Shnaiderman: Sov. Powder Metall. Met. Ceram., 14 (1975), 879.

39) V. K. Simonov and A. M. Grishin: Russ. Metall., 2013 (2013), 425.

40) Thermo-Calc Software AB: Thermo-calc: http://www.thermocalc.com, (accessed 2014-09-09). 